\title{
Analisis Komparatif Tingkat Kepuasan Mahasiswa antar Jurusan di Politeknik Negeri Padang terhadap Pelayanan Pendidikan
}

\author{
Zahara \\ Eliyanora \\ Yossi Septriani \\ Zalida Afni \\ Jurusan Akuntansi Politeknik Negeri Padang
}

\begin{abstract}
This study is aimed at identifying students' satisfactory levels toward educational services provided by Politeknik Negeri Padang (PNP) and further determine whether there is a gap between their expectation and actual services that they receive. We define educational services as services provided by lecturers, administration staffs, and managerial officers. It is also included students' perception on teaching-enhanced tools. The measurement of students' satisfactory level is conducted using 5 variables, i.e reliability, responsiveness, assurance, empathy and tangible. Moreover, these variables are operationalised through several questions. All answers of these questions use likert scale within the range of 1 to 4 . The score of students' satisfactory level of PNP is further converted to the standard of Quality Assurance Services for government organizations, referring to KEPMENPAN No. KEP/25/M.PAN/2/2004. This study finds that educational services provided by PNP is reasonably good. There is a gap between students' expectation level and actual services that they receive. On average, the score for their expectation is 3.71 whilst it is 2.59 for actual services (using the scale from 1 to 4). Of all departments in PNP, Accounting and Machinery Engineering has the lowest gap, 1.07 and 0.95 consecutively. Meanwhile, the highest gap occurs for Civil and Electrical Engineering, with score of 1.21. Overal, based on the Standard of Quality Assurance Services of KEPMENPAN No: KEP/25/M.PAN/2/2004, we conclude that students' satisfactory level for PNP is in " $B$ " category, indicating that the performance of its educational service is "good".
\end{abstract}

Key Word : Students' Satisfactory Level, Gab, Educational Services, Standard of Quality Assurance Services

\section{PENDAHULUAN}

Politeknik Negeri Padang (PNP) merupakan institusi pendidikan yang memiliki komitmen yang tinggi untuk menghasilkan pendidikan yang bermutu. Salah satunya dibuktikan dengan keberhasilan Politeknik Negeri Padang dalam memperoleh sertifikat ISO 9000:2001 tentang standar mutu pendidikan di perguruan tinggi. Keberhasilan PNP memperoleh ISO
9000:2001 ini, tentunya diharapkan juga dapat meningkatkan kepuasan mahasiswa (sebagai pemakai langsung jasa pendidikan) terhadap pelayanan pendidikan yang mereka terima, baik dari dosen, karyawan maupun fungsionaris/pengurus struktural. Oleh karenanya evaluasi dan pengukuran kepuasan mahasiswa terhadap pelayanan pendidikan di PNP perlu dilakukan. 
Salah satu bentuk evaluasi yang dapat dilakukan adalah dengan membandingkan tingkat harapan dan kepuasan yang dirasakan oleh mahasiswa terhadap pelayanan pendidikan yang telah mereka terima selama ini di PNP. Tingkat kepuasan mahasiswa tersebut nantinya juga dapat dikonversikan untuk mengukur kinerja unit PNP sebagai salah satu badan instansi pemerintah dalam memberikan pelayanan pendidikan mereka dengan merujuk kepada Surat Keputusan Menteri Pendayagunaan Aparatur Negara Nomor: KEP/25/M.PAN/2/2004 tentang Pedoman Umum Penyusunan Indeks Kepuasan Masyarakat Unit Pelayanan Instansi Pemerintah, tentang kepuasan pemakai jasa di lingkungan Unit Pelayanan Instansi Pemerintah. Pengukuran tentang sejauh mana institusi pendidikan mampu memenuhi harapan pelanggannya, dapat dijadikan titik tolak untuk menentukan mutu pelayanan pendidikan suatu institusi pendidikan. Dimana hal ini dinilai melalui evaluasi dan pengukuran tingkat kepuasan pemakai jasa pendidikan.

Penelitian ini bertujuan untuk menganalisis tingkat kepuasan mahasiswa antar jurusan yang ada di PNP terhadap sistem pelayanan pendidikan yang diberikan. Hasil yang diharapkan dari penelitian ini adalah diketahuinya apakah ada perbedaan (gap) harapan dan tingkat kepuasan mahasiswa di masing-masing Jurusan terhadap pelayanan pendidikan di PNP. Hasil penelitian ini juga akan menunjukkan tingkat kualitas pelayanan pendidikan PNP berdasarkan KEP/25/M.PAN/2/2004. Sehingga hasil dari penelitian ini diharapkan bisa menjadi salah satu masukan dan bahan evaluasi bagi PNP dalam meningkatkan kualitas/mutu pelayanan pendidikannya.

Dalam penelitian ini, tingkat kepuasan mahasiswa selaku pelanggan PNP terhadap jasa pelayanan pendidikan yang mereka terima, dapat diketahui dengan cara membandingkan antara harapan dengan kenyataan yang mereka rasakan. Hal ini merujuk kepada Kottler (1997) yang mendefinisikan kepuasan pelanggan sebagai kepuasan atau kekecewaan yang dirasakan oleh pelanggan setelah membandingkan antara harapan dengan kenyataan yang ada. Dimana kualitas jasa tersebut diukur dengan 5 aspek utama yaitu : (1) Reliability (Keandalan) yaitu kemampuan pelaksana untuk melaksanakan jasa yang dijanjikan kepada konsumen dengan tepat dan terpercaya. (2) Responsiveness (Daya Tanggap) yaitu ketanggapan pelaksana untuk membantu konsumen dan memberikan jasa dengan cepat dan tanggap. (3) Assurance (Kepastian) yaitu pengetahuan, kesopanan dan kemampuan pelaksana untuk menimbulkan keyakinan dan kepercayaan konsumen. (4) Empathy (Empati) yaitu rasa kepedulian pelaksana dalam memberikan perhatian lebih kepada konsumen. (5) Tangible (Berwujud) yaitu tampilan fasilitas fisik, peralatan dan media komunikasi yang membantu dalam pemberian jasa kepada konsumen.

Pengukuran tingkat kepuasan mahasiswa ini menggunakan kuisioner yang berisikan pernyataan yang terkait dengan kualitas pelayanan pendidikan yang diberikan oleh semua komponen pendidikan di PNP, yang dikelompokkan atas pelayanan pendidikan yang diberikan oleh dosen, karyawan, fungsionaris/struktural dan ketersediaan aset berujud untuk mendukung pelayanan pendidikan tersebut. Mahasiswa akan memberikan nilai untuk setiap pernyataan tersebut berkenaan dengan harapan (ekpektasi) mereka serta nilai untuk realisasi pelayanan yang mereka rasakan, sehingga akan diketahui apakah ada perbedaan (gab) antara harapan mahasiswa dengan realisasi atau tingkat kepuasan yang mereka rasakan terhadap pelayanan pendidikan tersebut.

Pernyataan yang digunakan dalam kuisioner untuk penelitian ini sama dengan pernyataan yang digunakan oleh Indahwati (2008) dalam penelitiannya. Pengukuran tingkat kepuasan mahasiswa ini diproksikan ke dalam 5 (lima) variabel, sebagaimana yang dikembangkan oleh Berry dan Parasuraman (1991), yaitu: (1). Keandalan (reliability) yaitu 
kemampuan dosen, karyawan dan fungsionaris (pengurus) jurusan dalam memberikan jasa sesuai dengan yang dijanjikan, (2). Daya tanggap (responsiveness) yaitu kemauan dari dosen, karyawan dan fungsionaris (pengurus jurusan) untuk membantu mahasiswa dan memberikan jasa dengan cepat dan berkualitas, termasuk dalam menanggapi keluhan yang dihadapi mahasiswa, (3). Kepastian (assurance) yaitu kemampuan dosen, karyawan dan fungsionaris (pengurus jurusan) untuk memberikan keyakinan kepada mahasiswa bahwa jasa yang diberikannya telah sesuai dengan ketentuan dan berkualitas, (4). Empati (empathy) yaitu kesediaan dosen, karyawan dan fungsionaris (pengurus jurusan) untuk lebih peduli memberikan perhatian secara pribadi kepada mahasiswa dan (5). Berwujud (tangible) yaitu persepsi mahasiswa terhadap penampilan fasilitas fisik, peralatan dan berbagai materi komunikasi yang digunakan dalam pelayanan.

Tingkat kepuasan mahasiswa masingmasing jurusan di PNP yang diperoleh dari penelitian ini dapat dikonversikan kepada standar mutu pelayanan pada lembaga pemerintahan yang memberikan pelayanan publik, mengacu kepada KEP/25/M.PAN/2/2004. Adanya surat keputusan ini merupakan salah satu upaya untuk meningkatkan kualitas pelayanan publik, sebagaimana diamanatkan dalam UndangUndang Nomor 25 tahun 2000 tentang Program Pembangunan Nasional. Sehingga PNP sebagai salah satu instansi pemerintah juga harus menilai tingkat kualitas jasa pelayanan mereka kepada mahasiswa sebagai salah satu komponen penerima jasa pendidikan mereka dengan mengacu kepada surat keputusan diatas.

Berdasarkan uraian diatas, masalah yang akan dibahas dalam penelitian ini adalah sebagai berikut : (1) Bagaimana tingkat harapan dan tingkat kepuasan mahasiswa di masing-masing jurusan terhadap pelayanan pendidikan di Politeknik Negeri Padang. (2) Apakah ada perbedaan (gap) antara harapan dan kepuasan yang dirasakan oleh mahasiswa di masing-masing jurusan terhadap pelayanan pendidikan di Politeknik Negeri Padang. (3) Bagaimanakah tingkat mutu pelayanan pendidikan di Politeknik Negeri Padang dengan mengacu kepada Surat Keputusan Menteri Pendayagunaan Aparatur Negara Nomor: KEP/25/M.PAN/2/2004 ?

Dengan demikian kontribusi nyata yang diharapkan dari hasil penelitian ini adalah terkait dengan pengembangan lembaga pendidikan khususnya bagi Politeknik Negari Padang (PNP) yang meliputi : (1) Bagi pimpinan dan staf struktural PNP, hasil penelitian ini dapat dijadikan salah satu sumber informasi dan bahan evaluasi terhadap pelayanan yang telah diberikan kepada mahasiswa. Sehingga PNP dapat mengetahui mengidentifikasi kelemahan-kelemahan yang masih perlu dibenahi dan ditingkatkan serta mempertahankan pelayanan yang sudah baik bagi kemajuan PNP dimasa yang akan datang. (2) Bagi dosen dan karyawan PNP, hasil penelitian ini juga dapat dijadikan masukan dan bahan evaluasi terhadap pelayanan yang telah mereka berikan kepada mahasiswa, untuk memperbaiki diri atas kekurangan yang ada dan mempertahankan hal-hal yang sudah baik. (3) Bagi mahasiswa PNP sendiri, penelitian ini juga bisa menjadi salah satu sarana untuk menyampaikan apresiasi mereka terhadap pelayanan pendidikan yang telah mereka terima dan rasakan selama ini.

\section{METODE PENELITIAN}

Metode penelitian yang digunakan dalam penelitian ini adalah metode deskriptif. Adapun rancangan penelitian yang dibangun adalah sebagai berikut : Tingkat kepuasan mahasiswa terhadap jasa pelayanan pendidikan yang mereka terima pada penelitian ini diukur dengan 5 (lima) variabel. Variabel-variabel tersebut merujuk dari penelitian Indahwati (2008) yang merujuk kepada penelitian Berry dan Parasuraman (1991) yaitu: (1) Keandalan (reliability), (2). Daya tanggap (responsiveness), (3). Kepastian (assurance), (4). Empati (empathy), (5). Berwujud (tangible). Variabel ke 1 - 4 ditujukan untuk menilai 
Analisis Komparatif Tingkat Kepuasan Mahasiswa antar Jurusan di Politeknik Negeri Padang ...

pelayanan yang diberikan oleh dosen, karyawan dan struktural PNP. Variabel ke 5 digunakan untuk menilai fasilitas fisik yang digunakan dalam proses pendidikan tersebut.Variabel-variabel tersebut di atas akan diuraikan menjadi butir-butir pertanyaan dalam kuisioner. Dimana alternatif jawaban setiap pertanyaan akan diukur dengan skala Likert yaitu : (1) Tidak Baik, (2) Kurang Baik, (3), Baik dan (4). Sangat Baik.

Pengolahan data menggunakan bantuan program Microsoft Excell untuk menghitung nilai mean (rata-rata) untuk menilai pelayanan yang diberikan oleh dosen, karyawan dan struktural serta fasilitas fisik yang digunakan dalam proses pendidikan tersebut. Sedangkan tingkat kualitas pelayanan yang diberikan oleh PNP sebagai instansi pemerintahan, diukur dengan mengkonversikan nilai kepuasan mahasiswa di setiap jurusan kepada standar mutu pelayanan dalam SK Nomor: KEP/25/M.PAN/2/2004 tentang Pedoman Umum Penyusunan Indeks Kepuasan Masyarakat Unit Pelayanan Instansi Pemerintah. Konversi nilai rata-rata kepuasan mahasiswa di masing-masing jurusan terhadap Indeks Kepuasan Masyarakat (IKM) tersebut dilakukan dengan pengelompokan sebagai berikut

Tabel: Nilai Persepsi, Interval IKM, Interval Konversi IKM, Mutu Pelayanan dan Kinerja Unit Pelayanan

\begin{tabular}{|c|c|c|c|c|}
\hline $\begin{array}{c}\text { NILAI } \\
\text { PERSEPSI }\end{array}$ & $\begin{array}{c}\text { NILAI } \\
\text { INTERVAL } \\
\text { IKM }\end{array}$ & $\begin{array}{c}\text { NILAI } \\
\text { INTERVAL } \\
\text { KONVERSI } \\
\text { IKM }\end{array}$ & $\begin{array}{c}\text { MUTU } \\
\text { PELAYANAN }\end{array}$ & $\begin{array}{c}\text { KINERJA } \\
\text { UNIT } \\
\text { PELAYANAN }\end{array}$ \\
\hline 1 & $1,00-1,75$ & $25-43,75$ & $\mathrm{D}$ & Tidak baik \\
\hline 2 & $1,76-2,50$ & $43,76-62,50$ & $\mathrm{C}$ & Kurang baik \\
\hline 3 & $2,51-3,25$ & $62,51-81,25$ & $\mathrm{~B}$ & Baik \\
\hline 4 & $3,26-4,00$ & $81,26-100,00$ & $\mathrm{~A}$ & Sangat baik \\
\hline
\end{tabular}

Data yang diolah dalam penelitian ini merupakan data primer. Pengumpulan data dilakukan dengan menggunakan kuisioner yang dibagikan kepada mahasiswa yang terpilih sebagai responden. Dimana reliabilitas dan validitas kuisioner diuji dengan teknik Pilot Testing yaitu dengan menguji terlebih dahulu kuisioner kepada sampel responden. Setelah kuisioner dianggap valid dan reliabel, baru kuisioner tersebut akan dibagikan kepada mahasiswa yang terpilih sebagai responden sebenarnya.

Populasi dari penelitian ini adalah keseluruhan mahasiswa PNP untuk semua program mulai dari tingkat I sampai dengan tingkat III. Pengambilan sampel dilakukan secara non probabilitas dengan metode Purposive Sampling dengan kriteria berdasarkan kepada pertimbangan (judgment). Metode pengambilan sample ini digunakan karena responden yang akan dipilih lebih difokuskan kepada kelompok mahasiswa program D.III Reguler dan Mandiri dengan pertimbangan jumlah mereka hampir $83 \%$ dari populasi dan mahasiswa tahun III merupakan mahasiswa yang paling lama menerima pelayanan yang diberikan oleh dosen, karyawan maupun fungsionaris. Total kuisioner adalah sebanyak 300 kuisioner yang dibagikan kepada 6 jurusan di PNP @ 50 kuisioner. kuisioner yang kembali dan dapat diolah sebanyak 255 (85\%) yang cukup memadai untuk dapat memberikan gambaran tingkat kepuasan mahasiswa atas pelayanan pendidikan yang mereka terima di PNP. 
Analisis data dilakukan dengan menghitung nilai rata-rata harapan dan kepuasan yang dirasakan oleh mahasiswa di setiap jurusan. Berdasarkan hasil perhitungan tersebut akan dapat diketahui gap (perbedaan) antara harapan dan kepuasan mahasiswa terhadap pelayanan jasa pendidikan di PNP yang mereka terima. Jika gap bernilai positif, artinya harapan mahasiswa lebih tinggi dari kenyataan yang mereka rasakan. Dan jika gap bernilai negatif berarti kepuasan yang dirasakan mahasiswa lebih tinggi dari ekspektasi/harapan yang mereka inginkan. Selanjutnya, untuk menganalisis tingkat mutu pelayanan di PNP dilakukan dengan mengkonversikan nilai rata-rata kepuasan mahasiswa setiap jurusan dengan nilai yang tercantum dalam SK Nomor 25/M.PAN/2/2004, seperti yang telah diuraikan dalam pengukuran variabel sebelumnya.

\section{HASIL DAN PEMBAHASAN}

Tingkat kepuasan mahasiswa atas jasa pelayanan pendidikan yang diberikan oleh dosen, karyawan, fungsionaris dilihat dari aspek keandalan (reliability), daya tanggap (responsiveness), kepastian (assurance), empati (empathy) dan berwujud (tangible). Sedangkan ketersediaan aset berwujud untuk mendukung pelayanan pendidikan yang diberikan dilihat dari aspek ketersediaan gedung dan fasilitas, tingkat bersihan dan keamanan sarana prasarana tersebut. Hasil penelitian menunjukkan secara rata-rata terdapat gab antara tingkat kepuasan mahasiswa atas pelayanan pendidikan, baik yang diberikan oleh dosen, karyawan, maupun struktural/ fungsionaris serta aset berwujud, dimana tingkat harapan mereka lebih tinggi dari tingkat kepuasan mereka. Nilai rata-rata masing-masing jurusan di PNP terhadap setiap aspek pelayanan pendidikan secara keseluruhan adalah sebagai berikut:

Tabel 1. Rata-rata Pelayanan Pendidikan di Politeknik Negeri Padang

Sumber : data primer diolah

Berdasarkan tabel 1 diatas, dapat dilihat tingkat harapan dan kepuasan mahasiswa masing-masing jurusan di PNP terhadap pelayanan pendidikan yang diberikan oleh dosen, karyawan, fungsionaris/ struktural dan aset berwujud dengan rincian sebagai berikut :

\section{$1 . \quad$ Dosen}

Sebagaimana yang sudah diuraikan pada bagian sebelumnya, bahwa pelayanan pendidikan yang diberikan oleh dosen dilihat dari aspek keandalan (reliability) yaitu kemampuan yang dimiliki dosen dalam 
memberikan pengajaran, daya tanggap (responsiveness) yang tergambar dari daya tanggap dosen dalam menanggapi keluhan mahasiswa terkait proses belajar mengajar, kepastian (assurance) yaitu kemampuan dosen dalam meyakinkan mahasiswa bahwa proses belajar mengajar yang dilakukan telah sesuai dengan ketentuan yang berlaku, empati (empathy) yaitu kesediaan dosen untuk memberikan perhatian secara pribadi terkait proses belajar mengajar.

Berdasarkan tabel.1 terlihat bahwa mahasiswa di Jurusan Akuntansi PNP memiliki harapan yang paling tinggi terhadap pelayanan pendidikan yang diberikan oleh dosen dibandingkan dengan mahasiswa di jurusan lainnya dengan indeks harapan sebesar 3,85. Harapan mahasiswa jurusan akuntansi atas pelayanan pendidikan yang diberikan oleh dosen tersebut juga lebih tinggi dari rata-rata harapan seluruh mahasiswa PNP.

Sedangkan mahasiswa di Jurusan Administrasi Bisnis memiliki harapan terendah atas pelayanan pendidikan yang diberikan oleh dosen diantara semua jurusan yang ada di PNP dengan indeks harapan sebesar 3,57. Artinya, mahasiswa di Jurusan Administrasi Bisnis tidak terlalu mengharapkan dosendosennya memberikan pelayanan pendidikan sebagaimana harapan mahasiswa terhadap dosen-dosennya di Jurusan Akuntansi.

Mahasiswa di Jurusan Akuntansi PNP juga merasakan kepuasan tertinggi atas pelayanan pendidikan yang diberikan oleh dosen-dosen di Jurusan Akuntansi dibandingkan dengan kepuasan mahasiswa di Jurusan lainnya dengan indeks kepuasan sebesar 2,84. Kepuasan mahasiswa di Jurusan Akuntansi juga lebih tinggi dari ratarata kepuasan seluruh mahasiswa PNP atas pelayanan pendidikan yang diberikan oleh dosen. Gap antara harapan dan kepuasan yang dirasakan oleh mahasiswa akuntansi juga lebih rendah dilihat dari gap rata-rata seluruh jurusan di PNP. Ini dapat dikatakan bahwa mahasiswa di Jurusan Akuntansi memiliki tingkat kepuasan yang mendekati harapan mereka dibandingkan dengan harapan mahasiswa pada Jurusan lain di PNP dimana dosen-dosen di Jurusan Akuntansi memiliki kemampuan yang memadai dalam memberikan pengajaran kepada mahasiswa, dosen-dosen dapat memberikan reaksi positif atas keluhan serta permasalahan yang dihadapi mahasiswa dalam proses belajar mengajar, dosen dapat memberikan keyakinan kepada mahasiswa bahwa materi dan metode pengajaran yang diberikan kepada mahasiswa sudah sesuai dengan rancangan pembelajaran sebagaimana yang telah ditetapkan dalam Kurikulum. Dosen juga memberikan perhatian secara pribadi kepada mahasiswa untuk membantu mahasiswa dalam proses belajar mengajar. Hal ini salah satunya dapat disebabkan karena Ilmu Akuntansi lebih spesifik dengan latar belakang mahasiswa yang berbeda-beda sehingga membutuhkan bimbingan dan arahan yang lebih dibandingkan dengan mahasiswa di Jurusan lain.

Indeks kepuasan terendah atas pelayanan pendidikan yang diberikan oleh dosen juga dirasakan oleh mahasiswa Jurusan Administrasi Bisnis dengan index sebesar 2,45 .

Gap tertinggi antara harapan dan kepuasan mahasiswa terhadap pelayanan pendidikan yang diberikan dosen dirasakan oleh mahasiswa di Jurusan Teknik Sipil dengan gap sebesar 1,20. Ini berarti kepuasan yang dirasakan oleh mahasiswa di Jurusan Teknik Sipil masih jauh dari harapan mereka. Sedangkan gap terendah adalah mahasiswa dari Jurusan Teknik Mesin dengan gap sebesar 0,94 . Artinya, pelayanan pendidikan yang diberikan oleh dosen di Jurusan Teknik mesin hampir sejalan dengan harapan mahasiswa.

\section{Karyawan}

Pelayanan pendidikan yang diberikan oleh karyawan dari aspek keandalan (reliability), dapat dilihat dari kemampuan karyawan dalam melaksanakan pekerjaan pelayanan kepada mahasiswa baik di tingkat jurusan maupun di tingkat PNP. Daya tanggap 
(responsiveness), dapat dilihat dari daya tanggap karyawan dalam menanggapi keluhan dan masalah yang dihadapi oleh mahasiswa terhadap pelayanan mereka. Kepastian (assurance), yaitu kemampuan karyawan dalam meyakinkan mahasiswa bahwa pelayanan yang diberikannya telah sesuai dengan ketentuan yang berlaku. Empati (empathy), yaitu kesediaan karyawan untuk memberikan perhatian secara pribadi terkait pelayanan yang diberikan guna membantu mahasiswa.

Berdasarkan tabel.1, Mahasiswa Jurusan Teknologi Informasi memiliki harapan yang paling tinggi atas layanan pendidikan yang diberikan oleh karyawan terhadap mahasiswa dengan indeks sebesar 3,76. Sedangkan mahasiswa di Jurusan Administrasi Bisnis memiliki harapan terendah atas pelayanan pendidikan yang diberikan oleh karyawan dengan indeks sebesar 3,53. Ini berarti bahwa mahasiswa Jurusan Administrasi Bisnis tidak berharap terlalu banyak atas pelayanan pendidikan yang diberikan oleh karyawan sebagaimana mahasiswa di Jurusan Teknologi Informasi.

Tabel 1. di atas juga menginformasikan bahwa mahasiswa Jurusan Akuntansi memiliki kepuasan tertinggi atas pelayanan yang diberikan oleh karyawan dengan indeks kepuasan sebesar 2,58, lebih tinggi dari indeks rata-rata kepuasan seluruh mahasiswa PNP. Artinya, meskipun ekspektasi mahasiswa Jurusan Akuntansi belum tercapai namun kepuasan yang mereka rasakan agar karyawan memiliki kemampuan dalam melaksanakan pekerjaan pelayanan kepada mahasiswa, memiliki daya tanggap yang tinggi dalam melayani mahasiswa khususnya mengenai urusan administrasi, karyawan dapat melayani mahasiswa dengan cepat dan berkualitas, adanya kepastian bahwa pelayanan pendidikan yang diberikan kepada mahasiswa sudah sesuai dengan ketentuan yang berlaku serta berharap agar karyawan dapat memberikan perhatian secara personal kepada mahasiswa mengenai masalah administrasi, memberikan kepuasan yang cukup memadai dibandingkan dengan kepuasan mahasiswa di Jurusan lain, karena kepuasan rata-rata atas pelayanan yang diberikan oleh karyawan pada mahasiswa Jurusan Akuntansi masih berada di atas ratarata keseluruhan jurusan.

Sedangkan mahasiswa Jurusan Teknik Sipil memiliki kepuasan terendah atas pelayanan yang diberikan oleh karyawan yang berarti bahwa pelayanan pendidikan yang diberikan oleh karyawan kepada mahasiswa Teknik Sipil belum dilakukan sepenuhnya oleh orang yang berkompeten, reaksi karyawan lambat dalam melayani mahasiswa, prosedur administrasi yang tidak jelas serta kurangnya rasa kepedulian karyawan dalam melayani mahasiswa dalam urusan administrasi.

Tingginya ekspektasi mahasiswa Jurusan Teknik Sipil atas pelayanan pendidikan yang diberikan oleh karyawan sementara di sisi lain kepuasan yang merasa rasakan rendah, menyebabkan gap antara harapan serta kepuasan yang dirasakan mahasiswa Jurusan Teknil Sipil tersebut menjadi paling tinggi diantara semua jurusan yang ada di PNP yaitu dengan gap sebesar 1,49 . Sedangkan gab tertinggi dirasakan oleh mahasiswa Jurusan Teknik Mesin dengan nilai 1,01 .

\section{Fungsionaris}

Pelayanan pendidikan yang diberikan oleh fungsionaris dari aspek keandalan (reliability), dilihat dari kemampuan fungsionaris dalam pelaksanaan tugasnya, fungsionaris memiliki kemampuan yang cakap dan memiliki kemampuan manajerial yang memadai. Daya tanggap (responsiveness), tergambar dari kecepatan daya tanggap fungsionaris dalam menanggapi keluhan dan masalah yang dihadapi oleh mahasiswa terkait dengan tugastugas mereka. Kepastian (assurance) yaitu kemampuan fungsionaris dalam meyakinkan mahasiswa bahwa pelayanan yang diberikan terkait tugas mereka telah sesuai dengan ketentuan yang berlaku. Empati (empathy) yaitu kesediaan fungsionaris untuk memberikan perhatian secara pribadi terkait tugas mereka guna membantu mahasiswa. 
Harapan tertinggi mahasiswa atas pelayanan pendidikan yang mereka terima dari fungsionaris/ struktural diperlihatkan oleh mahasiswa Jurusan Akuntansi dan mahasiswa Teknik Sipil dengan indeks harapan oleh mahasiswa di kedua jurusan ini sebesar 3,75. Tabel di atas juga memperlihatkan bahwa mahasiswa Jurusan Administrasi Bisnis memiliki harapan terendah atas pelayanan pendidikan yang diberikan oleh fungsionaris dengan indeks 3,52. Dapat dikatakan bahwa mahasiswa Administrasi Bisnis tidak memiliki harapan kepada fungsionaris sebagaimana ekspektasi mahasiswa di jurusan lain.

Kepuasan tertinggi atas pelayanan pendidikan yang diberikan oleh fungsionaris kepada mahasiswa diperlihatkan oleh mahasiswa Jurusan Akuntansi dengan index sebesar 2,75 dengan gab 1,00. Ini menandakan bahwa mahasiswa Jurusan Akuntansi cukup puas dengan pelayanan pendidikan yang diberikan oleh fungsionaris baik di tingkat jurusan ataupun di tingkat PNP karena kepuasan yang mereka rasakan cukup mendekati harapan mereka atas pelayanan pendidikan yang diberikan oleh fungsionaris. Namun di sisi lain mahasiswa Jurusan Administrasi Bisnis memiliki index sebesar 2,36 yang merupakan indeks kepuasan paling rendah atas pelayanan pendidikan yang diterima dari fungsionaris dibandingkan dengan mahasiswa pada jurusan lain.

Gap atas pelayanan pendidikan yang diberikan oleh fungsionaris kepada mahasiswa Jurusan Elektro dengan index kepuasan sebesar 1,21 merupakan gap tertinggi diantara semua jurusan yang ada di PNP. Artinya kepuasan yang dirasakan oleh mahasiswa Jurusan Elektro terhadap pelayanan pendidikan yang diberikan fungsionaris masih jauh dari harapan. Sedangkan gab terendah diperlihatkan oleh mahasiswa Jurusan Teknik Mesin dengan gab 0,80 yang berarti bahwa harapan atas pelayanan pendidikan yang diberikan oleh fungsionaris kepada mahasiswa jurusan Teknik Mesin sudah hampir sejalan dengan kepuasan yang mereka rasakan.

\section{Aset Berwujud}

Pelayanan pendidikan yang diterima oleh mahasiswa dilihat dari aset berwujud tergambar dari keadaan gedung di PNP, kondisi fasilitas belajar mengajar, kebersihan lingkungan serta keamanan di PNP.

Dari tabel.1 terlihat bahwa mahasiswa jurusan Teknik Sipil dan Teknologi Informasi memiliki ekspektasi yang sama atas aset berwujud dengan index harapan sebesar 3,87. Ini berarti bahwa mahasiswa di kedua jurusan tersebut mengharapkan tersedianya gedung perkuliahan yang memadai yang memberikan ketenangan serta kenyamanan dalam proses belajar mengajar, ketersediaan fasilitas pendukung proses belajar mengajar lainnya, serta terjaganya kebersihan dan keamanan lingkungan di PNP.

Kepuasan tertinggi serta gab terendah atas aset berwujud ini diperlihatkan oleh Jurusan Teknik sipil dengan index kepuasan sebesar 2,89 dan gab antara harapan dan kepuasan yang dirasakan mahasiswa sebesar 0,99 . Ini mengindikasikan bahwa meskipun masih ada yang harus dibenahi terkait aset tetap, namun harapan mahasiswa Juurusan Teknik Sipil mulai sejalan dengan kepuasan yang diperoleh.

\section{Rata-rata pelayanan pendidikan}

Berdasarkan rata-rata pelayanan pendidikan yang ada pada tabel.1, terlihat bahwa mahasiswa Jurusan Akuntansi memiliki kepuasan tertinggi atas pelayanan pendidikan yang diberikan oleh dosen, karyawan, fungsionaris dan aset berwujud jika dibandingkan dengan rata-rata pelayanan pendidikan yang diberikan pada Jurusan lain, dengan indeks kepuasan 2,72 serta gab 1,07. Sedangkan mahasiswa pada Jurusan Administrasi Niaga memiliki tingkat kepuasan terendah diantara semua jurusan di PNP dengan index sebesar 2,40. Rata-rata pelayanan pendidikan yang diperoleh oleh Jurusan Akuntansi seluruhnya berada di atas indeks rata-rata semua jurusan, baik dilihat dari pelayanan pendidikan yang diberikan oleh 
dosen, karyawan, fungsionaris maupun dari aset berwujud.

Gab tertinggi antara harapan dan kepuasan atas pelayanan pendidikan yang diberikan oleh dosen, karyawan, fungsionaris dan aset berwujud dimiliki oleh Jurusan Teknik Sipil dan Elektro yaitu 1,21. Tingginya gab tersebut disebabkan karena secara rata-rata mahasiswa Jurusan Teknik Sipil dan Elektro memiliki ekspektasi yang cukup tinggi atas pelayanan pendidikan yang diberikan oleh dosen, karyawan, fungsionaris dan aset berwujud namun dengan tingkat kepuasan yang lebih rendah dari Jurusan lain, khususnya jurusan Akuntansi. Disamping itu, rendahnya gab antara harapan dan kepuasan yang didapat oleh mahasiswa jurusan teknik mesin disebabkan karena ekspektasi mahasiswa jurusan teknik mesin yang lebih rendah dibandingkan dengan yang dirasakan oleh mahasiswa pada jurusan lain seiring dengan kepuasan yang mereka rasakan, dengan kata lain kepuasan yang dirasakan oleh mahasiswa di Jurusan Teknik Mesin cukup mendekati apa yang diharapkan oleh mahasiswa.

Tabel.2 Nilai Mutu Pelayanan Pendidikan dan Kinerja Unit Pelayanan di Politeknik Negeri Padang

Sumber : Data primer diolah

Sebagaimana yang sudah diuraikan pada bab terdahulu bahwa untuk mengukur tingkat kualitas pelayanan yang diberikan oleh PNP sebagai instansi pemerintahan, diukur dengan mengkonversikan nilai kepuasan mahasiswa kepada standar mutu pelayanan dalam Surat Keputusan Menteri

Pendayagunaan Aparatur Negara Nomor: KEP/25/M.PAN/2/2004 tentang Pedoman Umum Penyusunan Indeks Kepuasan Masyarakat Unit Pelayanan Instansi Pemerintah.

Dari table 2 di atas dapat dilihat kepuasan yang dirasakan oleh mahasiswa pada masing-masing Jurusan di PNP secara umum tingkat mutu bernilai " $B$ " dengan kinerja unit pelayanan "Baik" diperoleh oleh pelayanan yang diberikan oleh dosen, karyawan dan fungsionaris serta asset berwujud (tangible). Pelayanan pendidikan yang diperoleh mahasiswa pada masingmasing jurusan di PNP tersebut seluruhnya memperoleh tingkat mutu "B" kecuali pada Jurusan Administrasi Bisnis, mutu pelayanannya bernilai " $C$ " dengan kinerja unit pelayanan "kurang baik". Namun secara keseluruhan, Politeknik Negeri Padang memperoleh tingkat mutu "B" dengan kinerja pelayanan "Baik".

\section{KESIMPULAN DAN SARAN}

Dari hasil penelitian yang dilakukan dapat disimpulkan beberapa hal berikut : (1) Mahasiswa Jurusan Akuntansi memiliki tingkat kepuasan tertinggi atas pelayanan pendidikan yang diberikan oleh dosen, karyawan, fungsionaris dan aset berwujud jika 
dibandingkan dengan pelayanan pendidikan yang diberikan kepada mahasiswa pada Jurusan lain di PNP. (2) Mahasiswa pada Jurusan Administrasi Niaga memiliki tingkat kepuasan terendah diantara semua jurusan di PNP. (3) Gab tertinggi antara harapan dan kepuasan atas pelayanan pendidikan yang diberikan oleh dosen, karyawan, fungsionaris dan aset berwujud dimiliki oleh Jurusan Teknik Sipil dan Elektro. Tingginya gab tersebut disebabkan karena secara rata-rata mahasiswa Jurusan Teknik Sipil dan Elektro memiliki ekspektasi yang cukup tinggi atas pelayanan pendidikan yang diberikan oleh dosen, karyawan, fungsionaris dan aset berwujud namun dengan tingkat kepuasan yang lebih rendah dari Jurusan lain. (4) Rendahnya gab antara harapan dan kepuasan yang didapat oleh mahasiswa jurusan teknik mesin disebabkan karena kepuasan yang dirasakan oleh mahasiswa di Jurusan Teknik Mesin cukup mendekati apa yang diharapkan oleh mahasiswa. (5) Secara keseluruhan, mutu pelayanan di Politeknik Negeri Padang adalah "B" dengan kinerja pelayanan 'Baik".

Berdasarkan hasil penelitian di atas, penulis ingin menyarankan hal-hal berikut ini: (1) Untuk lebih meningkatkan pelayanan, segenap unsur Politeknik Negeri Padang baik dosen, karyawan maupun fungsionaris/ struktural untuk dapat meningkatkan keandalan (kemampuan), daya tanggap (respon), kepastian, empati sesuai dengan tugas dan lingkup kerjanya masing-masing, termasuk peningkatan pelayanan terkait dengan asset berwujud agar pelayanan yang diberikan dapat memberikan kepuasan terhadap mahasiswa. Sehingga kepuasan yang dirasakan oleh mahasiswa sesuai dengan apa yang mereka harapkan. (2) Untuk penelitian selanjutnya disarankan agar variabel penelitian dapat ditambahkan tidak terbatas hanya pada variabel keandalan (reliability), daya tanggap (responsiveness), kepastian (assurance), empati (empathy) dan asset berwujud (tangible). Namun dapat ditambahkan dengan variabel lainnya yang belum tercakup dalam penelitian ini. (3)
Jumlah responden juga dapat diperluas tidak hanya per jurusan yang ada di Politeknik Negeri Padang, namun dapat juga diperluas berdasarkan program studi. Responden juga dapat diperluas ke pihak - pihak eksternal lainnya seperti orangtua mahasiswa ataupun perusahaan yang pernah melakukan kerjasama dengan Politeknik Negeri Padang.

\section{DAFTAR PUSTAKA}

Artawan, I Made,SE. (2002) Strategi Meningkatkan Mutu pendidikan di Perguruan Tinggi, Mutiara Cyber Network.

Budiono, Bambang,Dr.Ir.ME, (2003) Kebutuhan Kurikulum Berbasis Kompetensi Industri bagi Politeknik, Makalah pada Seminar Kurikulum Politeknik Negeri Padang, 4 Desember 2003.

Forum Komunikasi Jurusan Kesehatan Gigi Politeknik Kesehatan Depkes RI.(2002) Membangun Kurikulum berbasis kompetensi.

Indahwati, Rini, SE.,Ak.,M.Si, (2008) Pengukuran Kepuasan Mahasiswa terhadap Pelayanan Pendidikan di Jurusan Akuntansi Politeknik Negeri Medan, makalah Simposium Nasional Akuntansi XI.

Jogianto,H.M., Prof.,Dr.,M.B.A.,Akt. (2004) Metodologi Penelitian Bisnis, Salah Kaprah dan PengalamanPengalaman, Yogyakarta : BPFE UGM.

$\begin{array}{rrr}\text { Nasution, } & \text { Zulkarimein }(2003) & \text { Kualitas } \\ & \text { Pembelajaran di } & \text { Universitas } \\ \text { Meningkat?, artikel pada Pikiran } & \text { Rakyat, Rabu } 17 \text { September } 2003 .\end{array}$ 
Suwardjono, Dr, (2004). Perilaku Belajar di Perguruan Tinggi, Makalah Seri Pendidikan, Yogyakarta.

Xiao, Z.Z. and Dyson, J.R. (1999) Chinese students' perception of good accounting teaching. Accounting Education, 8(4) 341-361, Taylor \&
Francis Ltd, http://www.tandf.co.uk/journals

Zahara, SE.,Ak and Rafi, M., SE., Ak (2005). Persepsi Mahasiswa Jurusan Akuntansi Politeknik Negeri Padang tentang Good Accounting Teaching, Makalah penelitian DIPA Politeknik Negeri Padang. 